\title{
The calcium-activated nonselective cation channel TRPM4 is essential for the migration but not the maturation of dendritic cells
}

\author{
Gaëtan Barbet ${ }^{1,2,3,7}$, Marie Demion 1,2,3,7, Ivan C Moura ${ }^{1,3,7}$, Nicolas Serafini ${ }^{1,2,3}$, Thibaut \\ Léger $^{1,2,3}$, François Vrtovsnik ${ }^{1,3,4}$, Renato C Monteiro ${ }^{1,3}$, Romain Guinamard ${ }^{5}$, Jean-Pierre \\ Kinet $^{6}$, and Pierre Launay ${ }^{1,2,3}$ \\ ${ }^{1}$ Institut National de la Santé et de la Recherche Médicale U699, Paris F-75018, France. \\ 2Equipe Avenir, Institut National de la Santé et de la Recherche Médicale, Paris F-75018, France. \\ ${ }^{3}$ Université Paris 7-Denis Diderot, Faculté de Médecine, Site Xavier Bichat, Paris F-75018, France. \\ ${ }^{4}$ Hôpital Bichat, Service de Néphrologie, Paris F-75018, France. \\ ${ }^{5}$ Laboratoire de Physiologie Cellulaire, EA 3212, Université de Caen, Caen, F-14032, France. \\ ${ }^{6}$ Department of Pathology, Beth Israel Deaconess Medical Center and Harvard Medical School, \\ Boston, Massachusetts 02215, USA.
}

\begin{abstract}
Dendritic cell (DC) maturation and migration are events critical for the initiation of immune responses. After encountering pathogens, DCs upregulate the expression of costimulatory molecules and subsequently migrate to secondary lymphoid organs. Calcium $\left(\mathrm{Ca}^{2+}\right)$ entry governs the functions of many hematopoietic cell types, but the role of $\mathrm{Ca}^{2+}$ entry in DC biology remains unclear. Here we report that the $\mathrm{Ca}^{2+}$-activated nonselective cation channel TRPM4 was expressed in and controlled the $\mathrm{Ca}^{2+}$ homeostasis of mouse DCs. The absence of TRPM4, which elicited $\mathrm{Ca}^{2+}$ overload, did not influence DC maturation but did considerably impair chemokine-dependent DC migration. Our results establish TRPM4-regulated $\mathrm{Ca}^{2+}$ homeostasis as crucial for DC mobility but not maturation and emphasize that DC maturation and migration are independently regulated.
\end{abstract}

Dendritic cells (DCs) are crucial in the initiation of adaptive immune responses. These 'professional' antigen-presenting cells, which are present in almost all peripheral tissues, capture and process antigens in the periphery before migrating to secondary lymphoid organs, where they prime naive $\mathrm{T}$ lymphocytes ${ }^{1}$. DC-mediated modulation of immune responses depends on the DC maturation status. During maturation, DCs undergo several phenotypic

\section{(C) 2008 Nature Publishing Group}

Correspondence should be addressed to P.L. (pierre.launay@inserm.fr)..

7 These authors contributed equally to this work.

Note: Supplementary information is available on the Nature Immunology website.

AUTHOR CONTRIBUTIONS G.B. and I.C.M. were responsible for all experiments involving in vivo analysis of Trpm4 ${ }^{-/-}$and Trpm $^{-1-}$ mice; M.D. did the electrophysiological experiments in the whole-cell configuration; R.G. did the electrophysiological experiments in the 'inside-out' configuration; G.B. and M.D. did Ca ${ }^{2+}$ imaging; G.B. did the Transwell assays; M.D. did the time-lapse experiments; T.L. contributed to biochemical experiments; N.S. was responsible for quantitative RT-PCR; G.B. and N.S. were responsible for genotyping of mice; J.-P.K. was responsible for the generation of Trpm $4^{-1}$ mice, critical reading and comments; R.C.M. and F.V. provided experimental guidance; all authors critically reviewed and contributed to the manuscript; and P.L. directed and supervised all aspects of the study and the writing and editing of the manuscript.

Reprints and permissions information is available online at http://npg.nature.com/reprintsandpermissions/

Accession codes

UCSD-Nature Signaling Gateway (http://www.signaling-gateway.org): A003857 and A003767. 
changes (such as up-regulation of the expression of costimulatory and major histocompatibility complex (MHC) class II molecules) that result in more potent antigen-presenting cell function. DC pattern-recognition receptors, including Toll-like receptors, are necessary for the sensing of pathogen-associated molecular patterns during microbial aggression. Hence, DCs act as 'sentinels', trafficking between tissues and lymph nodes to deliver signs of 'danger' to appropriate immune effector cells2. In the absence of foreign antigens, DCs remain in an immature state but are able to present self antigen and thus are involved in peripheral tolerance3. DCs are heterogenous and have been classified according to criteria such as their hematopoietic origin, surface marker expression, developmental stage, mobility and tissue localization4. For example, migratory DCs such as Langerhans cells and dermal DCs migrate from the peripheral tissues through the lymphatics to the draining lymphoid organs, whereas circulating DCs such as plasmacytoid DCs circulate in the bloodstream.

An increase in the cytosolic free calcium concentration $\left(\left[\mathrm{Ca}^{2+}\right]_{\mathrm{i}}\right)$ is a ubiquitous signal that influences a wide range of hematopoietic cell functions, including cell cycle progression, adhesion, maturation and mobility ${ }^{5}$. Cytoplasmic increases in $\mathrm{Ca}^{2+}$ concentration induced by antigen receptor engagement modulate the initiation and maintenance of many cell functions ${ }^{6,7}$. After bacterial or mechanical stimulation, $\mathrm{Ca}^{2+}$ fluxes are induced in DCs and between adjacent DCs by networks of nanotubes ${ }^{8}$. DC migration correlates with an influx of $\mathrm{Ca}^{2+}$ through $\mathrm{Ca}^{2+}$ release-activated $\mathrm{Ca}^{2+}$ channels ${ }^{9,10}$, and the engagement of chemokine receptors such as CCR7 triggers DC trafficking by considerably increasing $\mathrm{Ca}^{2+}$ influx ${ }^{11}$.

Thus, $\mathrm{Ca}^{2+}$ homeostasis seems to be a key determinant of DC activation, but the molecular mechanisms regulating the $\mathrm{Ca}^{2+}$ homeostasis of DCs are not well understood. The $\mathrm{Ca}^{2+}$ activated nonselective (CAN) channel TRPM4 (transient receptor potential melastatin 4; A003857) has been detected in hematopoietic cells at both molecular and functional levels ${ }^{12}$. The TRPM4 and TRPM5 (A003767) channels are the only CAN channels described so far in nonexcitable cells 13,14 . In physiological conditions, TRPM4 channels allow massive entry of $\mathrm{Na}^{+}$, thereby inducing membrane depolarization and decreasing the driving force for $\mathrm{Ca}^{2+}$ entry ${ }^{15}$. TRPM4 can regulate the amount of $\mathrm{Ca}^{2+}$ entry and related physiological responses of $\mathrm{T}$ lymphocytes and mast cells ${ }^{15,16}$.

To examine the function of $\mathrm{Ca}^{2+}$ homeostasis in DC biology, we generated and analyzed a TRPM4-deficient $\left(\mathrm{Trpm}^{-{ }^{-}}\right)$mouse model. We found that TRPM4 was expressed in and controlled the $\mathrm{Ca}^{2+}$ homeostasis of DCs. TRPM4, but not TRPM5, acted as a $\mathrm{Ca}^{2+}$ ' $g$ atekeeper', preventing $\mathrm{Ca}^{2+}$ overload in DCs. $\mathrm{Ca}^{2+}$-dependent stimulation of $\operatorname{Trpm} 4^{-1-}$ DCs promoted downregulation of the expression of phospholipase C- $\beta 2$ (PLC- $\beta 2$ ), which resulted in less subsequent $\mathrm{Ca}^{2+}$ mobilization in Trpm $4^{-/-}$cells. Furthermore, the migration of Trpm $4^{-1-}$ DCs was profoundly impaired, but their maturation was not affected. Thus, our results show that the maturation and migration of DCs are regulated differently.

\section{RESULTS}

\section{Fewer DCs in lymphoid organs of $\mathrm{Trpm}^{-/-}$mice}

To assess the function of $\mathrm{Ca}^{2+}$ in DC biology, we generated mice in which exons 3-6 of Trpm 4 were removed by Cre recombinase-mediated excision. Trpm $4^{-1-}$ mice lacked the targeted exons and TRPM4 protein (Supplementary Fig. 1 online) and were normal and fertile. The sizes of the thymus, spleen and lymph nodes of $\operatorname{Trpm}^{4^{-1-}}$ mice were similar to those of their $\operatorname{Trpm}^{H^{-/}}$littermates. Likewise, the numbers of $\mathrm{CD} 4^{+} \mathrm{T}$ cells, $\mathrm{CD} 8^{+} \mathrm{T}$ cells and $\mathrm{B}$ cells were similar in $\operatorname{Trpm}^{H^{--}}$and $\operatorname{Trpm}^{-{ }^{--}}$mice (data not shown).

However, we noted that the spleen of $\operatorname{Trpm} 4^{-1-}$ mice consistently had about $50 \%$ fewer CD $11 b^{+}$CD $11 c^{+}$DCs (Fig. 1a). The percentage and absolute number of plasmacytoid DCs in 
Trpm $4^{-1-}$ mice was normal (about $0.3 \%$; data not shown). Further phenotypic analysis showed that this effect was limited to specifically the CD8 $\alpha^{-}$subset; absolute numbers of CD $8 \alpha^{+}$DCs were not affected (Supplementary Fig. 2a online). However, the steady-state maturation status of $\operatorname{Trpm}^{-/-}$and Trpm $4^{+/+}$DCs was identical (Fig. 1b) independently of CD8 $\alpha$ expression (Supplementary Fig. 2b), as assessed by the expression of costimulatory and MHC class II molecules. We then assessed the maturation of DCs in inflammatory conditions in Trpm $4^{-1-}$ mice in vivo. After subcutaneous injection of Escherichia coli, the expression of CD86 and MHC class II was similar on DCs from Trpm $4^{-1-}$ and littermate control mice (Fig. 1c). However, the absolute number of mature DCs in draining lymph nodes was lower in Trpm $4^{-1-}$ mice (Fig. 1d). Thus, we noted fewer splenic DCs in steady-state conditions and fewer migratory DCs in inflammatory conditions in TRPM4-deficient mice. However, the absence of TRPM4 did not affect DC maturation.

\section{Impaired DC migration in Trpm4 ${ }^{-/-}$mice}

Cell mobility requires an increase in intracellular $\mathrm{Ca}^{2+}$. As TRPM4 is involved in $\mathrm{Ca}^{2+}$ homeostasis, and as the number of mature DCs in inflamed lymph nodes was lower in Trpm $4^{-/-}$mice, we further analyzed the effect of Trpm4 deletion on the homing of DCs to lymph nodes. After sensitization of skin with a proinflammatory agent, immature DCs begin to mature and migrate to the draining lymph nodes ${ }^{17}$. Thus, we painted the back skin of Trpm $4^{-1-}$ mice and littermate control mice with a $1 \%$ solution of fluorescein isothiocyanate (FITC) $2 \mathrm{~h}$ before inoculating the mice with $E$. coli by scarification. We isolated cells from brachial and mesenteric lymph nodes at 12, 24 and $48 \mathrm{~h}$ after scarification and counted FITC $^{+} \mathrm{CD} 11 \mathrm{c}^{+}$cells in lymph nodes by flow cytometry. We noted many fewer FITC $^{+} \mathrm{CD} 11 \mathrm{c}^{+}$cells in draining (brachial) lymph nodes of TRPM4-deficient mice at all time points studied (Fig. 2a). We found no such cells in nondraining (mesenteric) lymph nodes. However, the frequency of CD11 $\mathrm{c}^{+}$cells was similar in the skin of Trpm $4^{-/-}$and $\mathrm{Trpm} 4^{+/+}$ mice in steady-state conditions (Fig. 2b).

To confirm the defect in DC migration in $\operatorname{Trpm}^{{ }^{-/-}}$mice, we assessed the trafficking of adoptively transferred bone marrow-derived DCs (BMDCs) from Trpm $4^{-/-}$and Trpm $4^{+/+}$ mice. We labeled immature BMDCs (iDCs) from $\operatorname{Trpm} 4^{-/-}$and $\operatorname{Trpm} 4^{+/+}$mice differentially with the cytosolic dye CFSE $\left(\operatorname{Trpm}^{-/-}, \mathrm{CFSE}^{\mathrm{lo}} ; \operatorname{Trpm}^{+/+}, \mathrm{CFSE}^{\text {hi }}\right.$ ) and injected equal amounts of the cells together into footpads of recipient mice with the same genetic background (Fig. 2c). We induced DC migration by inoculating mice with $E$. coli at $2 \mathrm{~h}$ after BMDC transfer, then counted CFSE ${ }^{\text {hi }}$ and CFSE ${ }^{\text {lo }}$ DCs in popliteal lymph nodes 12, 24 and $48 \mathrm{~h}$ later. We detected significantly fewer Trpm $4^{-/-}$DCs in the popliteal lymph nodes at all time points (Fig. 2c). As expected, DC mobility was much lower in mice not inoculated with E. coli (Fig. 2c). These results collectively suggest that the impaired DC migration noted in TRPM4deficient mice was due to a DC-intrinsic defect.

\section{Absence of CAN current in Trpm4 ${ }^{-/-}$DCs}

The regulation of $\mathrm{Ca}^{2+}$ is essential for DC function; however, only a few studies have examined ionic channels in DCs ${ }^{10}$. Furthermore, of 28 members of transient receptor potential channels discovered, none have been studied in DCs ${ }^{18}$. Thus, we used the patch-clamp technique to measure TRPM4 channel activity in BMDCs.

We first compared the electrophysiological profiles of $\operatorname{Trpm} 4^{-/-}$and Trpm $4^{+/+}$BMDCs using the whole-cell configuration of the patch-clamp technique. We used an $\left[\mathrm{Ca}^{2+}\right]_{\mathrm{i}}$ of $1 \mu \mathrm{M}$ to promote the activation of CAN channels. We detected an outwardly rectifying current in wildtype but not in TRPM4-deficient BMDCs; in the latter, we detected only a residual inwardrectifying current (Fig. 3a). By subtracting the mean residual current-voltage relationships of Trpm $4^{-l-}$ DC traces from those of $\operatorname{Trpm} 4^{+/+}$DCs, we identified a TRPM4-like current (Fig. 
3a), as reported before for human embryonic kidney (HEK293) clones over-expressing TRPM4 (ref. 12).

We further characterized the TRPM4 current by studying cell-free excised membrane patches in the 'inside-out' configuration. We obtained typical single-channel recordings at several membrane potentials in symmetrical ionic conditions ${ }^{19}$ (Fig. 3b, inset). The corresponding current-voltage curve showed a linear conductance of $22.1 \pm 0.6 \mathrm{pS}$ ( $\mathrm{n}=6$ cells; Fig. $3 \mathrm{~b}$ ). Changing the internal solutions showed that the channel did not discriminate between $\mathrm{Na}^{+}$and $\mathrm{K}^{+}$and did not conduct $\mathrm{Cl}^{-}$(Fig. 3c). Channel activity was increased by membrane depolarization (Fig. 3d) and by an increase in $\left[\mathrm{Ca}^{2+}\right]_{\mathrm{i}}$, with a half-maximum effector concentration of $14 \mu \mathrm{M}$ (Fig. 3e,f), but was decreased by the internal application of ATP (Fig. $3 \mathrm{~g}$ ). Thus, our electrophysiology studies established that TRPM4 was expressed and functional in Trpm $4^{+/+}$BMDCs (20 of 42 'inside-out' patches) but not Trpm $4^{-/-}$BMDCs ( 0 of 58 'insideout' patches).

\section{TRPM4 is the main CAN channel regulating $\mathrm{Ca}^{2+}$ entry in DCs}

We next analyzed $\mathrm{Ca}^{2+}$ influx in $\mathrm{Trpm}^{-{ }^{--}}$and $\mathrm{Trpm} 4^{+/+}$iDCs by activation of the cells with an $E$. coli supernatant (ECS), as reported before ${ }^{8}$. We noted higher $\mathrm{Ca}^{2+}$ influx in $\mathrm{Trpm}^{4^{-1-}}$ iDCs than in Trpm $4^{+/+}$iDCs (Fig. 4a). To determine whether this was due to sustained $\mathrm{Ca}^{2+}$ entry or to the release of $\mathrm{Ca}^{2+}$ from internal stores, we incubated iDCs in $\mathrm{Ca}^{2+}$-free medium, stimulated them with ECS and added a solution of $2 \mathrm{mMCa}^{2+} 90 \mathrm{~s}$ later. We found no difference in $\mathrm{Ca}^{2+}$ release from internal stores (Fig. 4b), which suggested that the higher $\left[\mathrm{Ca}^{2+}\right]_{\mathrm{i}}$ in Trpm $4^{-1-}$ DCs was due to enhanced $\mathrm{Ca}^{2+}$ entry.

We next sought to determine what type of receptors were involved in the E. coli-mediated $\mathrm{Ca}^{2+}$ response of DCs. We tested whether G protein-coupled receptors, which are involved in the stimulation of DCs by Mycobacterium tuberculosis ${ }^{20}$, were involved in DC activation by E. coli. We incubated BMDCs overnight with pertussis toxin, an inhibitor of transduction through $\mathrm{G}$ protein-coupled receptors, then activated them with ECS. $\mathrm{Ca}^{2+}$-mediated signals induced by E. coli were abolished in the presence of pertussis toxin (Fig. 4c), which confirmed the interaction between $\mathrm{G}$ protein-coupled receptors and E. coli. Among G protein-coupled receptors expressed on iDCs, chemokine receptors such as CCR5 are involved in $\mathrm{Ca}^{2+}$ signals $^{20}$ and cell mobility ${ }^{21}$. Therefore, we assessed whether CCR5 was triggered by $E$. coli in DCs. Indeed, treatment with TAK-779, a potent antagonist of CCR5, resulted in much lower ECS-mediated $\mathrm{Ca}^{2+}$ signals in iDCs (Fig. 4d). E. coli can also directly bind to receptors for the Fc fragment of immunoglobulin G type III $(\mathrm{FcR} \gamma \mathrm{III})^{22}$; however, E. coli-induced $\mathrm{Ca}^{2+}$ signals in iDCs were not mediated by Fc receptors dependent on immunoreceptor tyrosine-based activation motifs, as iDCs from FcR $\gamma$-deficient mice had $\mathrm{Ca}^{2+}$ responses similar to those of control iDCs (Supplementary Fig. 3a online). These findings collectively indicate that Trpm $^{-1-}$ iDCs have a prolonged $\mathrm{Ca}^{2+}$ signal after E. coli triggering of $\mathrm{G}$ protein-coupled receptors, in particular chemokine receptors.

TRPM5 is closely related to TRPM4 in terms of electrophysiological properties, and we did detect TRPM5 transcripts by RT-PCR in DCs (Fig. 4e). However, we detected no other CAN current in Trpm $4^{-1-}$ DCs. Quantitative RT-PCR showed that TRPM4 mRNA was almost 200 times more abundant than TRPM5 mRNA in wild-type DCs, but that TRPM5 expression was three times higher in BMDCs from $\operatorname{Trpm} 4^{-/-}$mice than in those from littermate control mice (Fig. 4f). We therefore generated double-knockout Trpm $4^{-1-} \operatorname{Trpm}^{-1-}$ mice by mating our Trpm $4^{-1-}$ mice with $\operatorname{Trpm}^{-1-}$ mice ${ }^{23}$. After being stimulated with ECS, iDCs from Trpm $^{-1-}$ mice had $\mathrm{Ca}^{2+}$ responses identical to those of iDCs from wild-type mice, whereas Trpm $4^{-1-} \operatorname{Trpm}^{-1-}$ iDCs had a significantly higher $\mathrm{Ca}^{2+}$ flux than did Trpm $5^{-1-}$ iDCs (Fig. 4g). Trpm $4^{-1-} \operatorname{Trpm}^{-1-}$ mice also had fewer splenic DCs than did $\operatorname{Trpm} 5^{-1-}$ mice (Fig. 4h). 
These results show that TRPM4 is the main $\mathrm{Ca}^{2+}$-activated nonselective channel involved in $\mathrm{Ca}^{2+}$ homeostasis in mouse DCs and that TRPM5 cannot compensate for the lack of TRPM4.

\section{Enhanced $\mathrm{Ca}^{2+}$ influx affects only $\mathrm{DC}$ mobility}

As Trpm $4^{-1-}$ DCs had more $\mathrm{Ca}^{2+}$ influx after stimulation, we examined whether DC differentiation and maturation were also affected. We assessed the percentage of BMDCs $\left(\mathrm{CD} 11 \mathrm{c}^{+} \mathrm{CD} 11 \mathrm{~b}^{+}\right)$generated by the addition of granulocyte-macrophage colony-stimulating factor in vitro every $2 \mathrm{~d}$ from day 4 to day 13 . We noted similar differentiation of $\operatorname{Trpm} 4^{-/-}$ and $\operatorname{Trpm} 4^{+/+}$BMDCs (Fig. 5a).

To determine whether the higher $\left[\mathrm{Ca}^{2+}\right]_{\mathrm{i}}$ permitted by TRPM4 deficiency affected DC maturation, we assessed maturation induced by a $\mathrm{Ca}^{2+}$-independent stimulus (LPS) and a $\mathrm{Ca}^{2+}$-dependent stimulus (paraformaldehyde-fixed E. coli). As reported before ${ }^{24}$, activation with bacteria allowed $\mathrm{Ca}^{2+}$ influx, whereas LPS did not (Supplementary Fig. 3b,c). Each stimulus upregulated the expression of maturation markers (CD86, CD80, MHC class II and CCR7) to a similar extent in Trpm $4^{-/-}$and Trpm $4^{+/+}$BMDCs (Fig. 5b,c), which suggested that the enhanced $\mathrm{Ca}^{2+}$ influx due to Trpm4 deletion did not affect DC maturation. We also tested the rate of E. coli phagocytosis and DC survival after incubation with fixed bacteria. Each was similar in BMDCs from Trpm $4^{-/-}$and $\operatorname{Trpm} 4^{+/+}$mice (Supplementary Fig. 4a,b online). Therefore, maturation, differentiation and phagocytosis were not affected by $\mathrm{Ca}^{2+}$ overload in Trpm $4^{-1-}$ DCs.

Given the known function of $\mathrm{Ca}^{2+}$ in promoting cell mobility, the observed lower migration of Trpm $4^{-1-}$ DCs, which had large amounts of $\mathrm{Ca}^{2+}$, was unexpected. To further characterize the $\operatorname{Trpm}^{-/-}$DC mobility defect, we made time-lapse videos of $\operatorname{Trpm}^{{ }^{-/-}}$and control BMDCs after activation. We stimulated iDCs with ECS and measured their trajectories in twodimensional x-y projections every $5 \mathrm{~min}$ for $4 \mathrm{~h}$. Immature BMDCs from $\operatorname{Trpm} 4^{-1-}$ mice were more mobile than were those from $\operatorname{Trpm} 4^{+/+}$control mice (Fig. 6a).

However, because we had found that DC migration was impaired in $\operatorname{Trpm} 4^{-1-}$ mice in vivo, we then assessed oriented migration in response to the CCR7 ligand CCL21, which is involved in the trafficking of DCs to lymph nodes ${ }^{25,26}$. In Transwell chambers, we compared chemotaxis of DCs matured for $24 \mathrm{~h}$ with fixed $E$. coli or with LPS. The chemotaxis of $\operatorname{Trpm} 4^{-1-}$ mature DCs (mDCs) was significantly lower than that of $\operatorname{Trpm} 4^{+/+}$DCs when we used $E$. coli for cell maturation (Fig. 6b), but it was significantly higher than that of $\operatorname{Trpm}^{+/+}$DCs when we used LPS for maturation (Fig. 6c). This lower chemotaxis of E. coli-matured Trpm $4^{-1-}$ DCs was conserved even at higher concentrations of CCL21 (Supplementary Fig. 5 online). In contrast, mDCs from $\operatorname{Trpm}^{+/+}$mice showed similar chemotaxis after stimulation with either $E$. coli or LPS (Fig. 6b,c).

Because the in vitro experiments showed greater mobility of $\operatorname{Trpm} 4^{-1-}$ DCs after LPS maturation, we tested the effect of LPS on the migration of $\operatorname{Trpm}^{-1-}$ iDCs in vivo by adoptive transfer assay. We differentially labeled $\operatorname{Trpm} 4^{-/-}$and $\operatorname{Trpm} 4^{+/+}$iDCs with CFSE as described above, then injected the cells into the footpads of mice $2 \mathrm{~h}$ before LPS injection ( $50 \mathrm{ng}$ per footpad) and counted migratory CFSE ${ }^{+}$DCs $24 \mathrm{~h}$ after LPS injection. We detected significantly more Trpm $4^{-1-}$ DCs in the popliteal lymph nodes (Fig. 6d). These results collectively indicate that the alteration in $\mathrm{Ca}^{2+}$ homeostasis induced deregulation of DC migration but not DC maturation.

\section{$\mathrm{Ca}^{2+}$ overload modulates PLC- $\beta 2$ expression in $\mathrm{Trpm}^{-/-} \mathrm{mDCs}$}

Cell migration to lymph nodes involves chemokine receptors coupled to $\mathrm{G}$ proteins. One important component of chemokine receptor signaling pathways is PLC ${ }^{27}$. PLC produces 
inositol-1,4,5-triphosphate, which, by binding to its receptor on the endoplasmic reticulum, causes rapid release of $\mathrm{Ca}^{2+}$ from endoplasmic reticulum stores. As reported above, maturation of Trpm $4^{-/-}$DCs with E. coli resulted in less CCL21-mediated chemotaxis. Similarly, we found that $\mathrm{Ca}^{2+}$ entry after ECS stimulation was lower in mDCs from $\operatorname{Trpm}^{4^{--}}$than in those from $\operatorname{Trpm}^{+/+}$mice (Fig. 7a). We also noted this lower $\mathrm{Ca}^{2+}$ mobilization after CCL21 stimulation (Fig. 7b). The use of $\mathrm{Ca}^{2+}$-free medium showed that the defect in ECS-induced $\mathrm{Ca}^{2+}$ flux in Trpm $4^{-1-}$ mDCs was due to impaired release of $\mathrm{Ca}^{2+}$ from internal stores (Fig. 7c).

Furthermore, the release of $\mathrm{Ca}^{2+}$ stores induced by thapsigargin was identical in $\operatorname{Trpm} 4^{-1-}$ and $\operatorname{Trpm}^{+/+}$DCs (data not shown). These findings suggest that Trpm $4^{-/-} \mathrm{mDCs}$ have defects in signaling pathways 'upstream' of the release of $\mathrm{Ca}^{2+}$ stores.

To determine if initial augmented $\mathrm{Ca}^{2+}$ entry during the maturation process was responsible for the lower $\mathrm{Ca}^{2+}$ flux noted during subsequent cell stimulations, we incubated iDCs with $E$. coli and $2.1 \mathrm{mM}$ EGTA to decrease the $\mathrm{Ca}^{2+}$ concentration in the cell culture medium from 2 $\mathrm{mM}$ to $1 \mu \mathrm{M}$. Viability and maturation were similar for $\operatorname{Trpm}^{-{ }^{--}}$and $\operatorname{Trpm} 4^{+/+} \mathrm{DCs}$ after overnight treatment with 2.1 mM EGTA (data not shown). However, EGTA treatment resulted in identical $\mathrm{Ca}^{2+}$ responses induced by subsequent CCL21 stimulation of $\operatorname{Trpm} 4^{-/-}$and Trpm $4^{+/+} \mathrm{mDCs}$ (Fig. 7d). In addition, when we matured DCs with LPS in presence of $2.1 \mathrm{mM}$ EGTA, Trpm $4^{-/-}$DCs still showed subsequent higher $\mathrm{Ca}^{2+}$ influx than that of $\operatorname{Trpm} 4^{+/+}$DCs (Supplementary Fig. 6a online). As expected, by decreasing the external $\mathrm{Ca}^{2+}$ concentration to $1 \mu \mathrm{M}$ during Transwell assays, we abolished the CCL21-induced chemotaxis of LPSmatured DCs (Supplementary Fig. 6b). These data collectively emphasize the function of the initial $\mathrm{Ca}^{2+}$ influx in the alteration of subsequent CCL21-mediated responses (Supplementary Fig. 7 online).

We next assessed which 'upstream' signaling molecule were involved in this regulatory process. As PLC- $\gamma 2$ regulates the migration of B cells ${ }^{28}$ and PLC- $\gamma 1$ is involved in the unresponsiveness of T cells ${ }^{29,30}$, we tested various PLC isoforms for their involvement in the $\mathrm{Ca}^{2+}$-mediated regulation of DCs. We noted reproducibly lower PLC- $\beta 2$ expression in $E$. coli-matured Trpm $4^{-1-}$ BMDCs (Fig. 7e). The proteasome inhibitor epoxomicyn had no effect on the lower PLC- $\beta 2$ expression in E. coli-matured Trpm $4^{-1-}$ BMDCs (Supplementary Fig. 8 online). Moreover, overnight incubation with ionomycin, which mimics the $\mathrm{Ca}^{2+}$ overload noted in Trpm $4^{-/-}$DCs, triggered similarly lower PLC- $\beta 2$ expression in Trpm $4^{+/+}$DCs (Fig. $7 \mathrm{e})$. This result suggests that $\mathrm{Ca}^{2+}$ overload is sufficient to induce PLC- $\beta 2$ downregulation in $\mathrm{mDCs}$ independently of proteasome degradation. Our data are consistent with the consequences of $\mathrm{Ca}^{2+}$ overload induced by ionomycin in T cells ${ }^{29}$, in which PLC- $\gamma 1$ degradation leads to unresponsiveness of T cells. However, the intensity of the bands corresponding to PLC- $\gamma 1$ and PLC- $\gamma 2$ was similar in immature and mature DCs from Trpm $4^{-1-}$ and $\operatorname{Trpm} 4^{+/+}$mice (Fig. 7f). Therefore, sustained entry of $\mathrm{Ca}^{2+}$ into Trpm $4^{-1-}$ DCs resulted in lower PLC- $\beta 2$ expression and thus less $\mathrm{Ca}^{2+}$ mobilization during subsequent stimulations.

\section{DISCUSSION}

$\mathrm{Ca}^{2+}$ homeostasis is tightly regulated in hematopoietic cells, and the importance of $\mathrm{Ca}^{2+}$ influx in cell activation is widely acknowledged. DCs are central to the immune system, but little is known about the molecular mechanisms that control $\mathrm{Ca}^{2+}$ entry in DCs. To address the role of $\mathrm{Ca}^{2+}$ in DC function, we generated an animal model in which $\mathrm{Ca}^{2+}$ homeostasis was impaired by genetic ablation of Trpm 4 channels. Trpm 4 is a CAN channel that regulates $\mathrm{Ca}^{2+}$ influx by depolarizing the membrane and decreasing the $\mathrm{Ca}^{2+}$ driving force through store-operated channels ${ }^{15}$. In this study, we have shown that stimulation of DCs lacking Trpm4 led to intracellular $\mathrm{Ca}^{2+}$ overload with detrimental consequences for DC migration but not maturation. 
Although we noted impaired migration of Trpm4-deficient DCs to lymph nodes, DC maturation was not altered in Trpm4-deficient mice; thus, DC functions are differentially sensitive to $\left[\mathrm{Ca}^{2+}\right]_{\mathrm{i}}$ variations. Indeed, the maturation induced by a $\mathrm{Ca}^{2+}$-independent stimulus (LPS) and a Ca ${ }^{2+}$-dependent stimulus (E. coli) was identical for Trpm $4^{-1-}$ and $\operatorname{Trpm} 4^{+/+}$DCs. This indicated that the process of maturation in DCs is not directly affected by sustained $\mathrm{Ca}^{2+}$ entry.

Unlike maturation, the migration of DCs was highly dependent on variations in $\left[\mathrm{Ca}^{2+}\right]_{\mathrm{i}}$. In absence of Trpm4, DCs matured in a $\mathrm{Ca}^{2+}$-independent way (by LPS) had more chemotaxis and homing to the draining lymph nodes. In contrast, $\mathrm{Ca}^{2+}$-dependent (bacterial) maturation of Trpm $4^{---}$DCs led to intracellular $\mathrm{Ca}^{2+}$ overload and impaired migration. Thus, in inflammatory conditions and during DC activation with pathogens, Trpm 4 is needed to regulate initial $\mathrm{Ca}^{2+}$ influx. This 'fine tuning' of $\mathrm{Ca}^{2+}$ entry allows DCs to respond adequately to subsequent stimuli (such as chemokines). Therefore, in contrast to the common paradigm that an increase of $\mathrm{Ca}^{2+}$ influx is associated with an increase in cell activity, our results lead us to postulate that $\mathrm{Ca}^{2+}$ uptake must be tightly regulated to avoid DC unresponsiveness and that TRPM4 is essential to prevent such detrimental overactivation.

The relationship between $\left[\mathrm{Ca}^{2+}\right]_{\mathrm{i}}$ and cell mobility has also been studied in $\mathrm{T}$ lymphocytes. $\mathrm{T}$ cell immobilization correlates with an increase in intracellular $\mathrm{Ca}^{2+}$ that seems to induce a 'stop' signal ${ }^{31}$. $\mathrm{T}$ cell mobility has been shown to be decreased by sustained $\mathrm{Ca}^{2+}$ influx. In a nonselective environment, immature thymocytes move rapidly while maintaining low intracellular $\mathrm{Ca}^{2+}$ concentrations. Conversely, an increase in $\left[\mathrm{Ca}^{2+}\right]_{\mathrm{i}}$ is necessary and sufficient to abolish thymocyte mobility ${ }^{32}$. The $\mathrm{Ca}^{2+}$ ionophore ionomycin has been used in $\mathrm{T}$ cells to assess molecular pathways affected by $\mathrm{Ca}^{2+}$ overload $^{30}$. Such results show that in these cells, subsequent steps of stimulation are responsible for the degradation of PLC- $\gamma 1$, which drives them into an unresponsive state ${ }^{29}$. In B lymphocytes, another PLC isoform, PLC- $\gamma 2$, is involved in the regulation of cell migration and homing. B cells from PLC- $\gamma 2$-deficient mice show impaired migration controlled by CXC chemokines ${ }^{28}$. We found that neither PLC- $\gamma 1$ nor PLC$\gamma 2$ was affected by $\mathrm{Ca}^{2+}$ overload in DCs. The $\beta$-isoforms of PLC are expected to be essential for DC migration, as chemokine receptors that guide DCs to secondary lymphoid organs ${ }^{33}$, ${ }^{34}$ involve $G_{\alpha}$ protein family members that activate the $\beta$-isoforms of PLC enzymes ${ }^{6}$. We suggest that in inflammatory conditions, the downregulation PLC- $\beta 2$ induced by $\mathrm{Ca}^{2+}$ overload abrogates the homing of Trpm $4^{-1-}$ DCs to secondary lymphoid organs. Thus, specific PLC isoforms seem to be important in $\mathrm{Ca}^{2+}$-mediated regulation in a cell type-specific way.

TRPM5, the channel the most closely related to TRPM4, is also a CAN cation channel ${ }^{35}$. On the basis of our electrophysiological data, we estimate that the number of TRPM4 channels expressed at the cell surface is around 1,000 molecules per DC. Quantitative PCR showed that TRPM4 expression was almost 200 times higher than TRPM5 expression; thus, we estimate that each DC expresses only 5 or 6 TRPM5 molecules. Furthermore, we detected no CAN current in $\operatorname{Trpm} 4^{-/-}$DCs. In addition, TRPM5 is not inhibited by the internal application of $\mathrm{ATP}^{35}$, but we found that ATP suppressed DC CAN activity in 'inside-out' patch-clamp experiments. To further rule out the possibility of a contribution of TRPM5 channels to the $\mathrm{Ca}^{2+}$ homeostasis of DCs, we generated Trpm $4^{-I-} \operatorname{Trpm}^{-1-}$ double-knockout mice. Phenotypic and physiological analysis of Trpm $4^{-1-} \operatorname{Trpm}^{-1-}$ DCs showed that they were not different from Trpm $4^{-l-}$ Trpm $^{+/+}$DCs. Therefore, our data suggest that TRPM4 is the only CAN channel involved in the control of $\mathrm{DC} \mathrm{Ca}{ }^{2+}$ homeostasis.

The factors governing the migration of DCs from skin to lymph nodes have been studied extensively, but because of the difficulty in tracking subsets of migrating cells and DC precursors in vivo, less is known about DC trafficking in steady-state conditions ${ }^{36,37}$. Studies have shown that in addition to bone marrow, spleen is a lymphoid organ where DC precursors 
can seed and differentiate ${ }^{38,39}$. Also, findings indicate that mice lacking the receptor tyrosine kinase Flt 3 have impaired DC development ${ }^{40}$. This defect in peripheral DC homeostasis seems to be dependent on both progenitor migration and in situ conventional DC division ${ }^{40}$. Our data have shown that TRPM4-deficient mice had constitutively fewer splenic CD8 $\alpha^{-}$DCs. These lower numbers of DCs could be the result of impaired migration and/or development of Trpm $4^{-1-}$ DC precursors. Further detailed studies must be done to distinguish between these two possibilities.

Matured monocyte-derived DCs are increasingly being used as cancer immunotherapy treatments ${ }^{3}$. As successful priming of tumor-specific T cells necessitates that such mature DCs generated ex vivo have the ability to migrate to lymphoid organs and thus to respond to specific chemokines, our data suggest that care should be taken to avoid $\mathrm{Ca}^{2+}$ overload during $e x$ vivo maturation procedures ${ }^{41,42}$. In summary, our results have shown that TRPM4 prevents $\mathrm{Ca}^{2+}$ overload and thus permits the homing of DCs to draining lymph nodes. In addition, our findings emphasize that DC migration and maturation are independently regulated.

\section{METHODS}

\section{Mice}

Trpm $4^{-1-}$ mice were viable and fertile. Pups were born at the expected mendelian ratio. Doubleknockout mice were generated by intercrossing of $\operatorname{Trpm}^{-1-}$ and $\operatorname{Trpm} 5^{-1-}$ mice (provided by C.S. Zuker). Double-knockout mice were viable and fertile and had no noteworthy abnormalities. In all experiments, mice were 6-14 weeks of age and controls were littermates. Mice were housed in specific pathogen-free conditions and were handled in accordance with French and European directives.

\section{BMDC cultures}

Bone marrow cells were extracted from femurs and tibias. Cells were cultured at $37{ }^{\circ} \mathrm{C}$ and $5 \% \mathrm{CO}_{2}$ at a density of $0.5 \times 10^{6}$ cells per ml in Iscove's modified Dulbecco's medium (SigmaAldrich) containing 10\% (vol/vol) FCS (PAA Laboratories), $1 \mathrm{mM}$ glutamine (Invitrogen), 10 $\mu \mathrm{M} \beta$-mercaptoethanol (Sigma-Aldrich) and $20 \mathrm{ng} / \mathrm{ml}$ of granulocyte-macrophage colonystimulating factor from supernatants of J558 cells (mouse plasma-cytoma cell line of BALB/ c origin transfected with the gene encoding granulocyte-macrophage colony-stimulating factor). DCs were matured for $24 \mathrm{~h}$ by the addition of LPS (10 ng/ml; Sigma-Aldrich) or paraformaldehydefixed E. coli (K12 strain; $1 \times 10^{6}$ bacteria per $\left.\mathrm{ml}\right)$ to the culture medium. Where indicated, cells were matured in presence of $2.1 \mathrm{mM}$ EGTA to chelate free $\mathrm{Ca}^{2+}$ in medium from $1.92 \mathrm{mM}$ to $1 \mu \mathrm{M}$. E. coli fixation was done on bacteria growing in logarithmic phase with $1 \%(\mathrm{vol} / \mathrm{vol})$ paraformaldehyde.

\section{Flow cytometry}

Cells were immunostained with fluorochrome-conjugated monoclonal antibodies to mouse CD11c (HL-3), CD11b (M1/70), CD8a (53-6.7), I-Ab (AF6-120.1), CD80 (16-10A1) and CD86 (GL1; all from Becton Dickinson). Cells were stained for CCR7 with antibody to CCR7 (anti-CCR7; 4B12; Serotec); as described ${ }^{43}$. Data were acquired with a FACSCalibur (Becton Dickinson) and analyzed with FlowJo 8.3.3 software (TreeStar).

\section{In vivo maturation assays}

Mice were subcutaneously injected in the footpads with $1 \times 10^{8}$ E. coli in PBS. At $24 \mathrm{~h}$ after injection, popliteal lymph nodes were extracted and were treated with DNAse and collagenase. DCs were purified with CD11c microbeads according to the manufacturer's protocol (Miltenyi Biotec) and were analyzed by flow cytometry. 


\section{Homing assays}

Mice anesthetized with xylasin and ketamin (Sigma-Aldrich) were shaved and depilated. Mice were then painted with $150 \mu \mathrm{l}$ of a $1 \%$ (wt/vol) solution of FITC (isomer I; Sigma-Aldrich) in acetone and dibutylphtalate (1:1). At $2 \mathrm{~h}$ after skin painting, mice were scarified with $E$. coli. Cells from draining and nondraining lymph nodes were analyzed by flow cytometry 12,24 or $48 \mathrm{~h}$ after scarification.

\section{Migration of CFSE-labeled BMDCs}

Immature BMDCs from TRPM4-deficient or control mice were loaded with different concentrations of CFSE (carboxyfluorescein diacetate succinimidyl diester; Sigma-Aldrich). Cells in suspension $\left(1 \times 10^{8}\right.$ cells per $\left.\mathrm{ml}\right)$ were labeled by the addition of either $500 \mu \mathrm{M}$ $\left(\mathrm{CFSE}^{\mathrm{hi}}\right)$ or $50 \mu \mathrm{M}\left(\mathrm{CFSE}^{\mathrm{lo}}\right) \mathrm{CFSE}$ in PBS with $0.1 \%$ (wt/vol) BSA. Trpm $4^{-1-}$ and Trpm $4^{+/+}$BMDCs were then mixed in equivalent proportions, and $0.5 \times 10^{6}$ cells were injected in the footpads of recipient mice $2 \mathrm{~h}$ before injection of $E$. coli $\left(5 \times 10^{6}\right.$ bacteria per footpad) or LPS (50 ng per footpad). Single-cell suspensions from draining and nondraining lymph nodes were incubated with anti-CD11c and were analyzed by flow cytometry.

\section{Immunoblot}

The expression of TRPM4 (from intestine) and PLC (from iDCs and mDCs after incubation for $1 \mathrm{~h}$ at $37^{\circ} \mathrm{C}$ atadensityof $3 \times 10^{6}$ cells per ml, as reported29) was analyzed with $200 \mu \mathrm{g}$ or $25 \mu \mathrm{g}$ of total protein, respectively (concentration determined by Bio-Rad protein assay). Proteins were separated by $8 \%$ or $10 \%$ SDS-PAGE and were transferred to polyvinylidene difluoride membranes (Amersham). Protein expression was assessed by immunoblot analysis with the primary antibodies anti-PLC- $\gamma 1$ (2822; Cell signaling), anti-PLC- $\gamma 2$ (sc-407; Santa Cruz Biotechnology), anti-PLC- $\beta 2$ (sc-206; Santa Cruz Biotechnology), anti- $\beta$-actin (ACTN05 (C4); AbCam) and polyclonal anti-TRPM4 (produced with Proteogenix). Horseradish peroxidase-conjugated antibodies were anti-rabbit (NA934; Amersham) and antimouse (115-035-068; Jackson Immunoresearch Laboratories).

\section{$\mathrm{Ca}^{2+}$ measurement}

Cells were loaded and acquired as described ${ }^{15}$ (Supplementary Methods online). For flow cytometry, cells were loaded for $45 \mathrm{~min}$ with pluronic acid and a probe of the acetoxymethyl ester of the fluorescent $\mathrm{Ca}^{2+}$ indicator Fluo-4 (1 $\mu \mathrm{M}$; Invitrogen) in Kreb's solution (145 mM $\mathrm{NaCl}, 5 \mathrm{mM} \mathrm{KCl}, 1 \mathrm{mM} \mathrm{Na} 2 \mathrm{HPO}_{4}, 5 \mathrm{mM}$ glucose, $1 \mathrm{mM} \mathrm{CaCl}_{2}, 0.5 \mathrm{mM} \mathrm{MgCl}_{2}, 10 \mathrm{mM}$ HEPES and $0.1 \%(\mathrm{wt} / \mathrm{vol}) \mathrm{BSA}, \mathrm{pH}$ 7.4). Individual fluorescence values were then analyzed with FlowJo and Origin software to normalize the fluorescence with the first value according to the equation ( $\mathrm{F} / \mathrm{F} 0)-1$, where ' $\mathrm{F}$ ' is the fluorescence at specific time point and ' $\mathrm{F} 0$ ' is the fluorescence at time 0 . The area under the curve was calculated for each cell. Where specified, cells were treated for $18 \mathrm{~h}$ with pertussis toxin $(1 \mu \mathrm{g} / \mathrm{ml}$; Sigma-Aldrich) or for $5 \mathrm{~min}$ with TAK-779 (500 nM; National Institutes of Health AIDS Reagent Program).

\section{Transwell assays}

Chemotaxis was assessed in 8- $\mu \mathrm{m}$ Transwell chambers (Corning). Matured BMDCs $\left(1 \times 10^{5}\right.$ cells) were loaded into the upper chamber previously coated for $1 \mathrm{~h}$ with Iscove's modified Dulbecco's medium and 1\% (wt/vol) BSA, then CCL21 (25 ng/ml; R\&D systems) was added to lower chamber (in Iscove's modified Dulbecco's medium and 1\% (wt/vol) BSA), followed by incubation for $2 \mathrm{~h}$ at $37{ }^{\circ} \mathrm{C}$ and $5 \% \mathrm{CO}_{2}$. The chemotaxis index was calculated, with normalization of values to those obtained in conditions without CCL21. 


\section{Additional methods}

Information on PCR (primers, Supplementary Table 1 online), electrophysiology, cell-mobility assays and skin staining is available in the Supplementary Methods.

\section{Statistical analysis}

Statistical significance was calculated with the one-way analysis of variance test. $P$ values of less than 0.05 were considered significant.

\section{Supplementary Material}

Refer to Web version on PubMed Central for supplementary material.

\section{Acknowledgments}

We thank S.Y. Lin (ABgenomics) and B. Koller (University of North Carolina) for help with generation of Trpm $4^{-1-}$ mice; C.S. Zuker (University of California, San Diego) for $\operatorname{Trpm}^{-1-}$ mice; E. Ferrary for help with the patch-clamp setup; M. Benhamou and U. Blank for advice and critical reading of the manuscript; and J. Bex, A. Bouhalfaïa and E. Couchi for help in animal care. Supported by the Association pour la Recherche sur le Cancer (G.B.), Institut National de la Santé et de la Recherche Médicale (M.D. and P.L.), Ministère de l'Enseignement Supérieur et de la Recherche, Université Paris 7 (N.S.), Fondation pour la Recherche Médicale (T.L. and P.L.) and Action Concertée Incitative Jeunes Chercheurs (P.L.).

\section{References}

1. Steinman RM, Hawiger D, Nussenzweig MC. Tolerogenic dendritic cells. Annu. Rev. Immunol 2003;21:685-711. [PubMed: 12615891]

2. Bonasio R, von Andrian UH. Generation, migration and function of circulating dendritic cells. Curr. Opin. Immunol 2006;18:503-511. [PubMed: 16777395]

3. Banchereau J, Palucka AK. Dendritic cells as therapeutic vaccines against cancer. Nat. Rev. Immunol 2005;5:296-306. [PubMed: 15803149]

4. Naik SH. Demystifying the development of dendritic cell subtypes, a little. Immunol. Cell Biol 2008;86:439-452. [PubMed: 18414430]

5. Lewis RS. Calcium signaling mechanisms in T lymphocytes. Annu. Rev. Immunol 2001;19:497-521. [PubMed: 11244045]

6. Feske S. Calcium signalling in lymphocyte activation and disease. Nat. Rev. Immunol 2007;7:690702. [PubMed: 17703229]

7. Scharenberg AM, Humphries LA, Rawlings DJ. Calcium signalling and cell-fate choice in B cells. Nat. Rev. Immunol 2007;7:778-789. [PubMed: 17853903]

8. Watkins SC, Salter RD. Functional connectivity between immune cells mediated by tunneling nanotubules. Immunity 2005;23:309-318. [PubMed: 16169503]

9. Partida-Sanchez S, et al. Regulation of dendritic cell trafficking by the ADP-ribosyl cyclase CD38: impact on the development of humoral immunity. Immunity 2004;20:279-291. [PubMed: 15030772]

10. Hsu S, et al. Fundamental Ca2+ signaling mechanisms in mouse dendritic cells: CRAC is the major Ca2+ entry pathway. J. Immunol 2001;166:6126-6133. [PubMed: 11342632]

11. Scandella E, et al. CCL19/CCL21-triggered signal transduction and migration of dendritic cells requires prostaglandin E2. Blood 2004;103:1595-1601. [PubMed: 14592837]

12. Launay $\mathrm{P}$, et al. TRPM4 is a Ca2+-activated nonselective cation channel mediating cell membrane depolarization. Cell 2002;109:397-407. [PubMed: 12015988]

13. Nilius B, et al. Regulation of the Ca2+ sensitivity of the nonselective cation channel TRPM4. J. Biol. Chem 2005;280:6423-6433. [PubMed: 15590641]

14. Prawitt $\mathrm{D}$, et al. TRPM5 is a transient $\mathrm{Ca} 2+$-activated cation channel responding to rapid changes in $\left[\mathrm{Ca}^{2+}\right]_{i}$. Proc. Natl. Acad. Sci. USA 2003;100:15166-15171. [PubMed: 14634208]

15. Launay P, et al. TRPM4 regulates calcium oscillations after T cell activation. Science 2004;306:13741377. [PubMed: 15550671] 
16. Vennekens R, et al. Increased IgE-dependent mast cell activation and anaphylactic responses in mice lacking the calcium-activated nonselective cation channel TRPM4. Nat. Immunol 2007;8:312-320. [PubMed: 17293867]

17. Macatonia SE, Knight SC, Edwards AJ, Griffiths S, Fryer P. Localization of antigen on lymph node dendritic cells after exposure to the contact sensitizer fluorescein isothiocyanate. Functional and morphological studies. J. Exp. Med 1987;166:1654-1667. [PubMed: 3119761]

18. Clapham DE. SnapShot: mammalian TRP channels. Cell 2007;129:220. [PubMed: 17418797]

19. Demion M, Bois P, Launay P, Guinamard R. TRPM4, a Ca ${ }^{2+}$-activated non-selective cation channel in mouse sino-atrial node cells. Cardiovasc. Res 2007;73:531-538. [PubMed: 17188667]

20. Floto RA, et al. Dendritic cell stimulation by mycobacterial Hsp70 is mediated through CCR5. Science 2006;314:454-458. [PubMed: 17053144]

21. Sanchez-Sanchez N, et al. Chemokine receptor CCR7 induces intracellular signaling that inhibits apoptosis of mature dendritic cells. Blood 2004;104:619-625. [PubMed: 15059845]

22. Pinheiro da Silva F, et al. CD16 promotes Escherichia coli sepsis through an FcRg inhibitory pathway that prevents phagocytosis and facilitates inflammation. Nat. Med 2007;13:1368-1374. [PubMed: 17934470]

23. Zhang Y, et al. Coding of sweet, bitter, and umami tastes: different receptor cells sharing similar signaling pathways. Cell 2003;112:293-301. [PubMed: 12581520]

24. MacAry PA, et al. HSP70 peptide binding mutants separate antigen delivery from dendritic cell stimulation. Immunity 2004;20:95-106. [PubMed: 14738768]

25. Forster R, et al. CCR7 coordinates the primary immune response by establishing functional microenvironments in secondary lymphoid organs. Cell 1999;99:23-33. [PubMed: 10520991]

26. Gunn MD, et al. Mice lacking expression of secondary lymphoid organ chemokine have defects in lymphocyte homing and dendritic cell localization. J. Exp. Med 1999;189:451-460. [PubMed: 9927507]

27. Hubbard KB, Hepler JR. Cell signalling diversity of the Gqa family of heterotrimeric G proteins. Cell. Signal 2006;18:135-150. [PubMed: 16182515]

28. de Gorter DJ, et al. Bruton's tyrosine kinase and phospholipase Cg2 mediate chemokine-controlled B cell migration and homing. Immunity 2007;26:93-104. [PubMed: 17239630]

29. Heissmeyer V, et al. Calcineurin imposes T cell unresponsiveness through targeted proteolysis of signaling proteins. Nat. Immunol 2004;5:255-265. [PubMed: 14973438]

30. Macian F, Im SH, Garcia-Cozar FJ, Rao A. T-cell anergy. Curr. Opin. Immunol 2004;16:209-216. [PubMed: 15023415]

31. Donnadieu E, Bismuth G, Trautmann A. The intracellular Ca2+ concentration optimal for T cell activation is quite different after ionomycin or CD3 stimulation. Pflugers Arch 1995;429:546-554. [PubMed: 7617445]

32. Bhakta NR, Oh DY, Lewis RS. Calcium oscillations regulate thymocyte motility during positive selection in the three-dimensional thymic environment. Nat. Immunol 2005;6:143-151. [PubMed: 15654342]

33. Randolph GJ, Ochando J, Partida-Sanchez S. Migration of dendritic cell subsets and their precursors. Annu. Rev. Immunol 2008;26:293-316. [PubMed: 18045026]

34. Sanchez-Sanchez N, Riol-Blanco L, Rodriguez-Fernandez JL. The multiple personalities of the chemokine receptor CCR7 in dendritic cells. J. Immunol 2006;176:5153-5159. [PubMed: 16621978]

35. Ullrich ND, et al. Comparison of functional properties of the Ca2+-activated cation channels TRPM4 and TRPM5 from mice. Cell Calcium 2005;37:267-278. [PubMed: 15670874]

36. Lindquist RL, et al. Visualizing dendritic cell networks in vivo. Nat. Immunol 2004;5:1243-1250. [PubMed: 15543150]

37. Ohl L, et al. CCR7 governs skin dendritic cell migration under inflammatory and steady-state conditions. Immunity 2004;21:279-288. [PubMed: 15308107]

38. Naik SH, et al. Intrasplenic steady-state dendritic cell precursors that are distinct from monocytes. Nat. Immunol 2006;7:663-671. [PubMed: 16680143]

39. Naik SH, et al. Development of plasmacytoid and conventional dendritic cell subtypes from single precursor cells derived in vitro and in vivo. Nat. Immunol 2007;8:1217-1226. [PubMed: 17922015] 
40. Waskow C, et al. The receptor tyrosine kinase Flt3 is required for dendritic cell development in peripheral lymphoid tissues. Nat. Immunol 2008;9:676-683. [PubMed: 18469816]

41. Mailliard RB, et al. $\alpha$-type-1 polarized dendritic cells: a novel immunization tool with optimized CTLinducing activity. Cancer Res 2004;64:5934-5937. [PubMed: 15342370]

42. Ten Brinke A, Karsten ML, Dieker MC, Zwaginga JJ, van Ham SM. The clinical grade maturation cocktail monophosphoryl lipid A plus IFNg generates monocyte-derived dendritic cells with the capacity to migrate and induce Th1 polarization. Vaccine 2007;25:7145-7152. [PubMed: 17719152]

43. Del Prete A, et al. Regulation of dendritic cell migration and adaptive immune response by leukotriene B4 receptors: a role for LTB4 in up-regulation of CCR7 expression and function. Blood 2007;109:626-631. [PubMed: 16985179] 

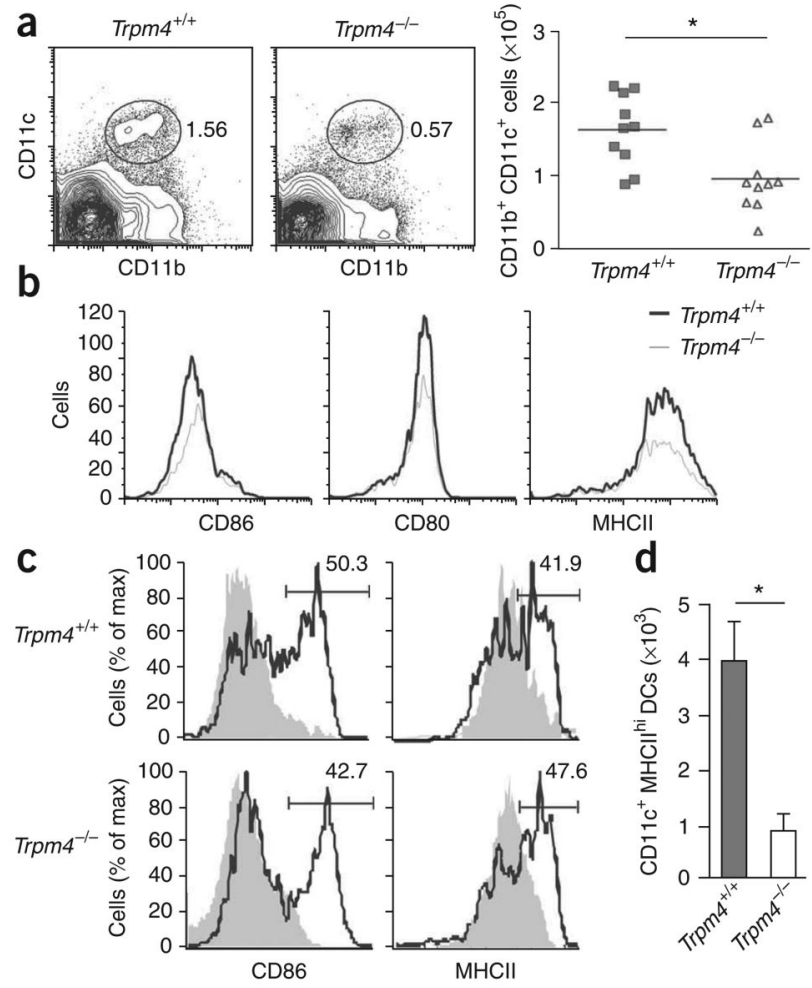

Figure 1.

DC populations in TRPM4-deficient and littermate control mice. (a) Staining profiles (left) and absolute numbers (right) of splenic CD11 $\mathrm{c}^{+} \mathrm{CD} 11 \mathrm{~b}^{+} \mathrm{DCs}$ from TRPM4-deficient mice $\left(\right.$ Trpm $\left.^{-{ }^{--}}\right)$and control mice $\left(\right.$Trpm $\left.4^{+/+}\right)$. Numbers adjacent to outlined areas (left) indicate percent $\mathrm{CD} 11 \mathrm{c}^{+} \mathrm{CD} 11 \mathrm{~b}^{+}$cells. Each symbol (right) represents an individual mouse; small horizontal lines indicate the mean. (b) Flow cytometry of the expression of costimulatory markers on spleen DCs from TRPM4-deficient and control mice. (c) Flow cytometry of the expression of CD86 and MHC class II molecules (MHCII) on popliteal lymph node DCs in steady-state conditions (filled histograms) and $24 \mathrm{~h}$ after subcutaneous injection of $E$. coli (bold lines). Numbers above bracketed lines indicate percent CD86 ${ }^{+}$cells (left) or MHC class IIhigh cells (right). (d) Absolute numbers of CD11 $\mathrm{c}^{+}$, MHC class II-high (MHCII ${ }^{\text {hi }}$ ) DCs in popliteal lymph nodes $24 \mathrm{~h}$ after subcutaneous injection of $E$. coli into TRPM4-deficient and control mice. *, $P<0.01$. Data are representative of ten $(\mathbf{a}, \mathbf{b})$ or six $(\mathbf{c}, \mathbf{d})$ independent experiments (error bars (d), s.e.m.). 

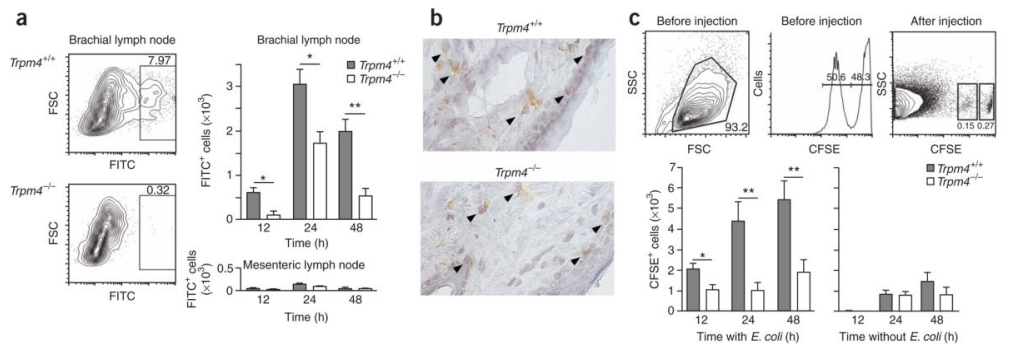

Figure 2.

Impaired migration of DCs in Trpm $4^{-1-}$ mice. (a) Flow cytometry of CD $11 \mathrm{c}^{+}$gated cells from lymph nodes of Trpm $^{-1-}$ and littermate control mice painted with a $1 \%$ solution of FITC on the back skin $2 \mathrm{~h}$ before the addition of $E$. coli by scarification. Left, numbers above outlined areas indicate percent ITC $^{+} \mathrm{CD} 11 \mathrm{c}^{+}$cells in draining (brachial) lymph nodes $12 \mathrm{~h}$ after scarification. FSC, forward scatter. Right, absolute numbers of FITC ${ }^{+}$CD $11 c^{+}$cells at 12, 24 and $48 \mathrm{~h}$ in draining (brachial) lymph nodes and nondraining (mesenteric) lymph nodes. (b) Immunohistochemistry of uninflamed skin from $\operatorname{Trpm}^{-1-}$ and control mice stained with antiCD11c and counterstained with hematoxylin. Arrowheads indicate CD11 $\mathrm{c}^{+}$cells. Original magnification, $\times 400$. (c) Flow cytometry of a 1:1 mixture of iDCs from Trpm4 $4^{-1-}$ mice $\left(\mathrm{CFSE}^{\mathrm{lo}}\right)$ and control mice $\left(\mathrm{CFSE}^{\mathrm{hi}}\right)$ before and after injection into the footpads of recipient mice at $2 \mathrm{~h}$ before $E$. coli inoculation (top row); far right, BMDCs detected in popliteal lymph nodes of recipients at $12 \mathrm{~h}$ after $E$. coli footpad injection. Number adjacent to outlined area (far left) indicates percent $\mathrm{CFSE}^{+}$cells from popliteal lymph nodes; numbers above bracketed lines (middle) and below outlined areas (right) indicate percent CFSE $^{\text {lo }}$ cells (left) or CFSE ${ }^{\text {hi }}$ cells (right). SSC, side scatter. Below, absolute numbers of migrated BMDCs in popliteal lymph nodes of mice with (left) or without (right) E. coli injection. * $P<0.05$; **, $P<0.01$. Data are representative of at least three independent experiments (error bars (a,c), s.e.m.). 

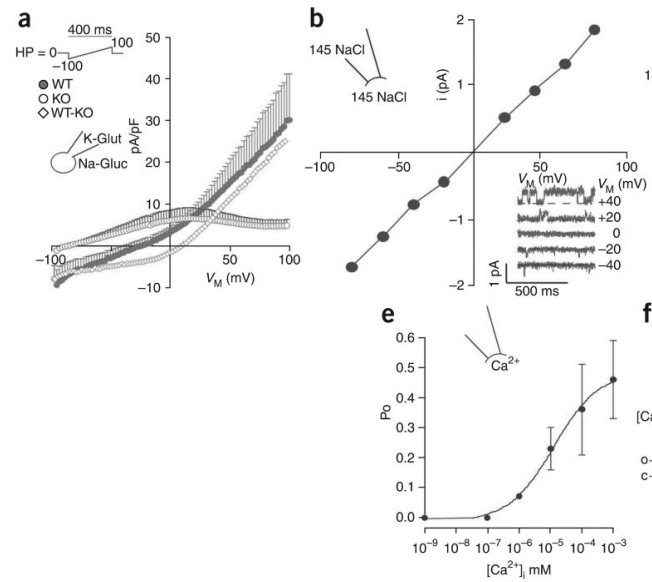

c

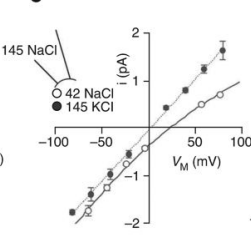

$f$
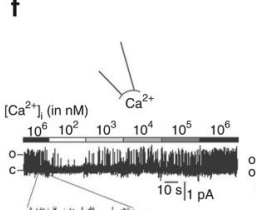

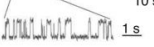

d

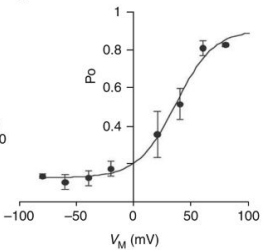

g

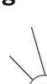

Figure 3.

A TRPM4-like current is present in Trpm $4^{+/+}$BMDCs but not in Trpm $4^{-1-}$ BMDCs. (a) Current-voltage relationships recorded in $\operatorname{Trpm}_{4}^{+/+}$and $\operatorname{Trpm}^{-/-}$BMDCs in the whole-cell patch-clamp configuration. The pipette solution contained mainly potassium glutamate (Kglut) with $1 \mu \mathrm{M} \mathrm{Ca}^{2+}$; the external solution contained mainly sodium gluconate (Na-gluc). The reversal potential was $-43.98 \pm 15.72 \mathrm{mV}$ in $\operatorname{Trpm}^{+/+}$DCs and $-79.72 \pm 5.08 \mathrm{mV}$ in $\operatorname{Trpm} 4^{-/-}$DCs $(P=0.032)$. The diamond curve results from subtraction of the $\operatorname{Trpm} 4^{+/+}$values from the $\operatorname{Trpm} 4^{-1-}$ values. HP, holding potential; $V_{\mathrm{M}}$, membrane potential. (b-g) Inside-out recordings. (b) Current-voltage curve obtained with both pipette and bath containing a standard solution of $145 \mathrm{mM} \mathrm{NaCl}$ with $1 \mathrm{mM} \mathrm{CaCl}_{2}$. Points were fitted by linear regression to determine conductance (g $22.1 \pm 0.6 \mathrm{pS})$. Inset, current traces at various voltages; dashed line, closed channel. (c) Current-voltage curves in $145 \mathrm{mM} \mathrm{KCl}$ (conductance, $22.3 \pm 1.4=\mathrm{pS}$; reversal potential, $1.7 \pm 1.2 \mathrm{mV}$; $\mathrm{K}^{+}$permeability $/ \mathrm{Na}^{+}$permeability, $0.95 \pm 0.04$ ) or in $42 \mathrm{mM} \mathrm{NaCl}$ (open circles); points were fitted by the Goldman-Hodgkin-Katz equation (reversal potential, $22.3 \pm 1.5 \mathrm{mV} ; \mathrm{Cl}^{-}$permeability/ $\mathrm{Na}^{+}$permeability, 0.11). (d) Channel voltage dependence, showing the open probability (Po) determined at various voltages in experiments identical to that in b. (e) Open probability at various $\left[\mathrm{Ca}^{2+}\right]_{i}$ values $\left(V_{\mathrm{M}}+40 \mathrm{mV}\right)$. Points were fitted with the Hill equation, which provided a half-maximum effector concentration of $14 \mu \mathrm{M}$. (f) Effect of $\left[\mathrm{Ca}^{+}\right]_{\mathrm{i}}$ on unitary channel $=$ activity $\left(V_{\mathrm{M}}+40 \mathrm{mV}\right) . \mathrm{c}$, closed state of the channel; $\mathrm{o}$, open state of the channel. (g) Effect of internal ATP on an inside-out patch. o1, open state of one channel; =o2, open state of two channels. Right, effect of ATP on the open probability. *, $P<$ 0.01. Data are representative of at least five $(\mathbf{a}, \mathbf{d})$ or four $(\mathbf{b}, \mathbf{c}, \mathbf{e}-\mathbf{g})$ independent experiments (error bars (c-e,g), s.e.m.). 


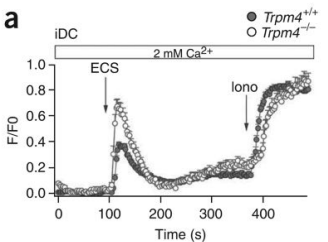

e

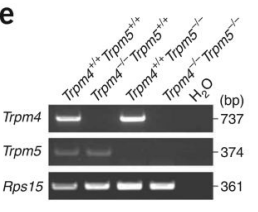

f
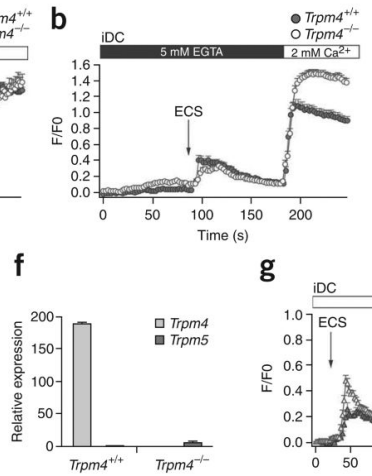

g

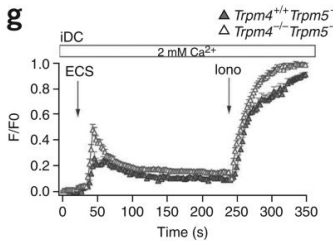

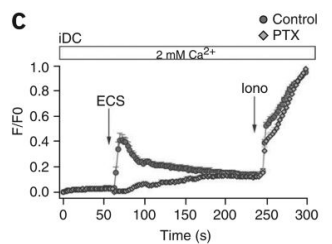

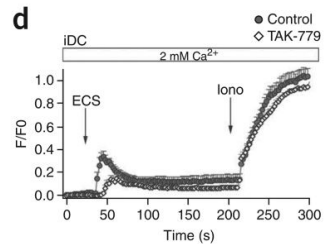

h

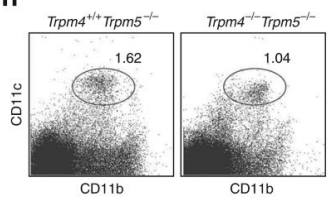

Figure 4.

Trpm4 is the main DC CAN channel regulating $\mathrm{Ca}^{2+}$ signaling. (a) Entry of $\mathrm{Ca}^{2+}$ into iDCs after activation by ECS, assessed in Trpm $4^{+/+}$BMDCs $(n=46$ cells $)$ and Trpm $4^{-1-}$ BMDCs $\left(n=51\right.$ cells). Area under the curve in arbitrary units (AU): $22.23 \pm 1.82 \mathrm{AU}, \operatorname{Trpm} 4^{+/+} ; 33.58$ $\pm 2.36 \mathrm{AU}, \operatorname{Trpm}_{4}^{-1-} ; P=0.0003$. Iono, ionomycin. (b) $\mathrm{Ca}^{2+}$ signaling in $\operatorname{Trpm}^{+/+} \mathrm{iDCs}(n$ $=54)$ and $\operatorname{Trpm}^{-1-}$ iDCs $(n=104)$ after ECS stimulation in $\mathrm{Ca}^{2+}$-free solution (5 mM EGTA) with the subsequent addition of $2 \mathrm{mM} \mathrm{Ca}^{2+}$. Area under the curve: $102.38 \pm 9.86 \mathrm{AU}$,

Trpm4 $=+/+; 139.71 \pm 7.42 \mathrm{AU}, \operatorname{Trpm}_{4}^{-/-} ; P=0.003$. (c) $\mathrm{Ca}^{2+}$ signals in Trpm $4^{+/+}$BMDCs with or without pretreatment with pertussis toxin: $14.07 \pm 2.52 \mathrm{AU}$ with pertussis toxin $(n=$ 28 cells); $35.33 \pm 3.51$ AU without pertussis toxin (Control; $n=26$ cells); $P=0.00001$. (d) $\mathrm{Ca}^{2+}$ signals in $\operatorname{Trpm}^{+/+}$BMDCs with or without TAK-779 treatment: $15.15 \pm 2.48$ AU with TAK-779 ( $n=43$ cells); $27.6 \pm 2.52$ AU without TAK-779 (Control; $n=32$ cells); $P=0.0009$. (e) RT-PCR of the expression of Trpm4 and TRPM5 mRNA in BMDCs. Rps15, small ribosomal protein (positive control); $\mathrm{H}_{2} \mathrm{O}$, no DNA. bp, base=pairs. (f) Quantitative RT-PCR of the expression of Trpm 4 and Trpm 5 in Trpm $4^{+/+}$and Trpm $4^{-/-}$BMDCs, presented relative to the expression of Rps14 (which decodes ribosomal protein 14). (g) $\mathrm{Ca}^{2+}$ signals in Trpm $4^{+/+} \operatorname{Trpm}^{-/-}$BMDCs $\left(25.6 \pm 4 \mathrm{AU} ; n=24\right.$ cells) and Trpm $4^{-l-} \operatorname{Trpm} 5^{-/-}$BMDCs (38.6 $\pm 2.3 \mathrm{AU} ; n=28$ cells $) ; P=0.006 . P=0.375$, wild-type $\left(\operatorname{Trpm} 4^{+/+} \operatorname{Trpm}^{+/+}\right)$versus

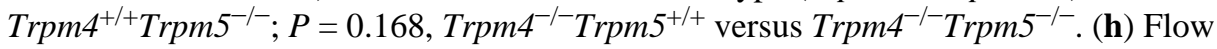
cytometry of steady-state splenic DCs. Numbers above outlined areas indicate percent $\mathrm{CD} 11 \mathrm{c}^{+} \mathrm{CD} 11 \mathrm{~b}^{+}$cells. Data are representative at least three independent experiments (error bars (f), s.e.m.). 

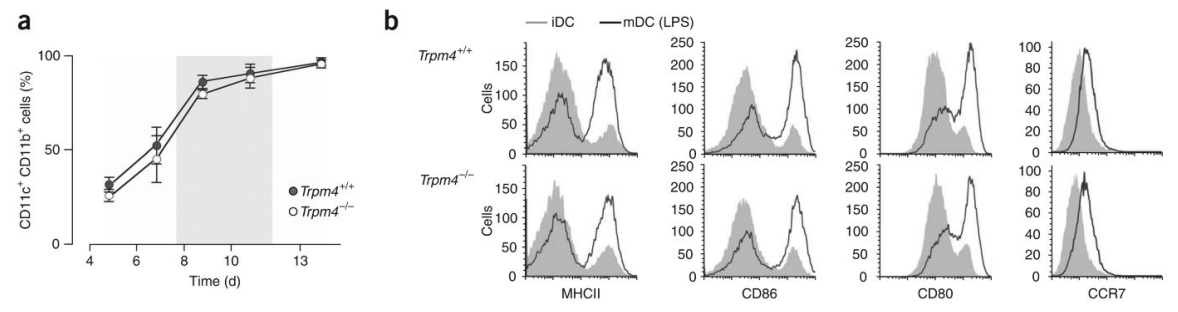

C
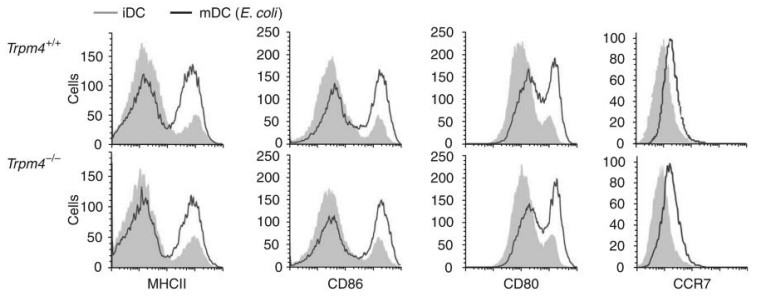

Figure 5.

Identical differentiation and maturation of $\operatorname{Trpm} 4^{-/-}$and $\operatorname{Trpm} 4^{+/+}$BMDCs. (a) Generation of CD11 $\mathrm{c}^{+}-\mathrm{CD} 11 \mathrm{~b}^{+}$BMDCs during in vitro culture. Gray shading indicates the culture period during which BMDCs were used for experiments. (b,c) Flow cytometry of the surface phenotypes of $\operatorname{Trpm} 4^{+/+}$and $\operatorname{Trpm} 4^{-/-}$BMDCs before (iDC) and after (mDC) $24 \mathrm{~h}$ of stimulation with LPS (b) or fixed E. coli (c). Data are representative of three independent experiments (error bars (a), s.e.m.). 

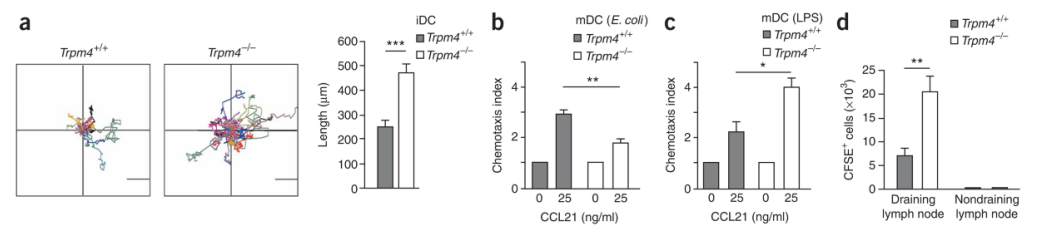

Figure 6.

Greater mobility but less chemotaxis of $\operatorname{Trpm} 4^{-1-}$ iDCs. (a) Time-lapse video microscopy (4 h) of the mobility of $\operatorname{Trpm} 4^{+/+}$iDCs $(n=26)$ and $\operatorname{Trpm}^{4^{--}}$iDCs $(n=25)$ after stimulation with fixed E. coli (left); colored lines indicate the movement of single cells every $5 \mathrm{~min}$. Scale bars, $100 \mu \mathrm{m}$. Right, mean distance. (b,c) Transwell migration of Trpm $4^{+/+}$and $\operatorname{Trpm}^{4^{-/-}}$

BMDCs triggered by CCL21 $(25 \mathrm{ng} / \mathrm{ml})$ after $24 \mathrm{~h}$ of maturation with fixed $E$. coli $(\mathbf{b})$ or LPS (c), assessed as the ratio of chemotaxis with CCL21/chemotaxis without CCL21. $P=0.0008$, fixed $E$. coli versus LPS for Trpm $4^{-1-}$ BMDCs; $P=0.087$, fixed $E$. coli versus LPS for Trpm $4^{+/+}$BMDCs. (d) In vivo migration of Trpm $4^{-/-}$(CFSE $^{\text {lo }}$ ) and control (CFSE ${ }^{\text {hi }}$ ) iDCs injected as a 1:1 mixture into the footpads of recipient mice $2 \mathrm{~h}$ before LPS injection $(50 \mathrm{ng} /$ footpad), presented as the absolute number of migrated BMDCs of each genotype in popliteal (Draining) and brachial (Nondraining) lymph nodes $24 \mathrm{~h}$ after LPS injection. *, $P<0.05$; **, $P<0.01$; **, $\mathrm{P}$ o 0.001 . Data are representative of at least three independent experiments (error bars, s.e.m.). 

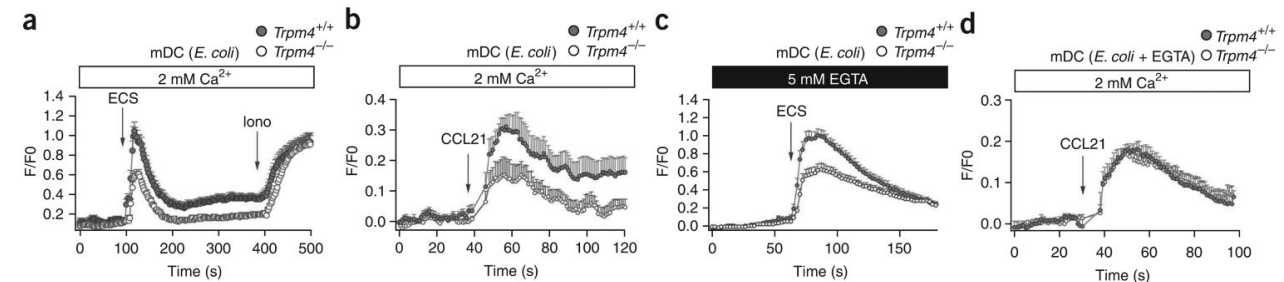

e
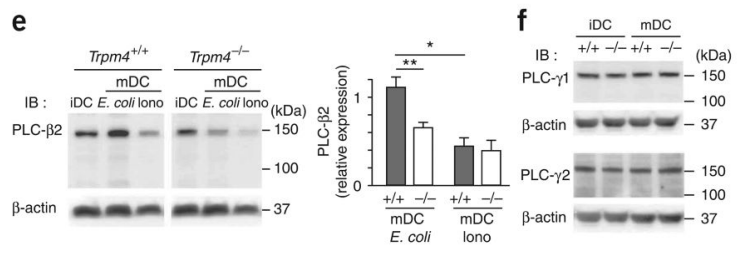

Figure 7.

PLC- $\beta 2$ downregulation induced by $\mathrm{Ca}^{2+}$ overload in $\operatorname{Trpm}^{-1-}$ DCs. (a) $\mathrm{Ca}^{2+}$ signals after ECS stimulation of Trpm $4^{+/+}$BMDCs $(122.82 \pm 12.43 \mathrm{AU} ; n=57$ cells $)$ and Trpm $4^{-/-}$BMDCs $(68.93 \pm 6.13 \mathrm{AU} ; n=64$ cells $)$ matured by stimulation with fixed $E$. coli. $P=0.0001 .=(\mathbf{b})$ $\mathrm{Ca}^{2+}$ signals after CCL21 stimulation of Trpm $4^{+/+}$and $\operatorname{Trpm}^{-/-}$BMDCs matured with fixed E. $\operatorname{coli}\left(19.31 \pm 4.59 \mathrm{AU}, \operatorname{Trpm}^{+/+} ; 8.58 \pm 6.49 \mathrm{AU}, \operatorname{Trpm}^{-1-} ; P=0.038\right)$. (c) $\mathrm{Ca}^{2+}$ signals after ECS stimulation of Trpm $4^{+/+}$mDCs $(80.9 \pm 10.5 \mathrm{AU} ; n=70$ cells $)$ and Trpm $4^{-1-}$ mDCs $(48.6 \pm 8.6 \mathrm{AU} ; n=57$ cells $)$ in the absence of external $\mathrm{Ca}^{2+} . P=0.0007$. (d) CCL21-mediated $\mathrm{Ca}^{2+}$ responses of $\mathrm{Trpm}^{+/+}$and $\mathrm{Trpm}^{-/-}$BMDCs matured with E. coli in the presence of EGTA. (e) PLC- $\beta 2$ protein expression $=$ in $\operatorname{Trpm}^{+/+}(+/+)$and $\operatorname{Trpm}^{-/-}(-/-)$BMDCs before (iDC) and after $E$. coli maturation or after $24 \mathrm{~h}$ of incubation with ionomycin $(1 \mu \mathrm{M})$. Right, PLC- $\beta 2$ expression relative to that of $b$-actin, normalized to iDC values. ${ }^{*}, P<0.05 ; * *, P<$ 0.01. (f) Expression of PLC- $\gamma 1$ and PLC- $\gamma 2$ in Trpm $4^{+/+}$and Trpm4 ${ }^{-/-}$BMDCs before and after $\mathrm{Ca}^{2+}$-dependent maturation. $\beta$-actin serves as a loading control. Data are representative of three (a,c,f), at least five (b,d), or eleven (e) independent experiments (error bars (e), s.e.m.). 